\title{
Abbreviations of Frequently Cited Materials
}

Brzopisni zapisnici

$D G F P$

Dokumenti o protunarodnom radu

F.O.

Greueltaten

Hronologija I94I-I945

Kriegstagebuch

Naprijed 1943

Narodnoosvobodilna vojna

"Neuhausen I"
Croatia, Independent State of. Brzopisni zapisnici Prvog zasjedanja Hrvatskog drzavnog sabora u Nezavisnoj Državi Hrvatskoj godine 1942. Zagreb, 1942.

United States, Department of State. Documents on German Foreign Policy, I 9 I 8-1 945. Series D, vols. I I-I3. Washington, D.C., 1960-64.

Horvat, Joža, and Zdenko Štambuk, eds. Dokumenti o protunarodnom radu i zlocinima jednog dijela katolickog klera. Zagreb, 1946.

United Kingdom, Foreign Office.

Croatia, Independent State of, Ministry of Foreign Affairs. Greueltaten und Verwüstungen der Aufrübrer im Unabhängigen Staate Kroatien in den ersten Lebensmonaten des kroatischen Nationalstaates. Zagreb, June 1942.

Yugoslavia, F. P. R. of, Vojnoistorijski institut. Hronologija oslobodilačke borbe naroda Jugoslavije, I94 I-1945. Belgrade, 1964 .

Germany, Wehrmacht, Oberkommando. Kriegstagebuch des Oberkommandos der Wehrmacht (Wehrmachtführungsstab), 1940-1945. 4 vols. in 7 pts. Frankfurt am Main, I961-65.

United States, National Archives.

Microcopy _, Roll _, Frame

Communist Party of Croatia. Dokumenti historije Komunističke partije Hrvatske. Vol. 3, bk. I, Naprijed I 943 . Reprint, Zagreb, I95I.

Yugoslavia, F. P. R. of, Military History Institute of the Yugoslav People's Army and the Institute for Historical Events in Ljubljana. Narodnoosvobodilna vojna na Slovenskem, 194 I-r 945. Zdravko Klanjšček, ed. 2nd ed. Ljubljana, 1977. United States, National Archives. Microcopy No. T-r 20, Roll 5796. "Bericht des Generalbevollmächtigten für die Wirtschaft in Serbien über die Zeit von Mitte April bis Ende Juli r94r." 
"Neuhausen II"

"Neuhausen III"

Proces proti Rupniku

Proleter Reprint

Quellen

RG

Das Schicksal der Deutschen in Jugoslawien

Sudjenje... Stepincu

W.O. -

YA, Mil. Hist.

-Commission on

Crimes

-Croatia Docs.

-Enemy Units

- German Docs.

-Nat'l. Lib. War

-Nedić Govt. Docs.

YA, Wkrs. Mvmt.,

Com. Party.

ZAVNOH dokumenti r943 [r944]

Zbornik DNOR
United States, National Archives. Microcopy No. T-75, Roll 69. "Zweiter Gesamtbericht des Generalbevollmächtigten für die Wirtschaft in Serbien, Juli I942."

United States, National Archives. Microcopy No. T-50I, Roll 260, Frames 320-4 I 7. "Die Wirtschaftslage im Bereich des Kommandierenden Generals und Befehlshabers in Serbien" [March I6, I944].

Yugoslavia, F. P. R. of, [People's Republic of Slovenia]. Proces proti vojnim zlocincem in izdajalcem Rupniku, Rösenerju, Rožmanu, Kreku, Vizjaku, in Hacinu. Ljubljana, 1946.

Yugoslavia, F. P. R. of, Institute for the Study of the Workers' Movement. Proleter: organ Centralnog komiteta Komunističke partije Jugoslavije, I929-1942. Reprint, Belgrade, I968.

Ferenc, Tone, ed. Quellen zur nationalsozialistischen Entnationalisierungspolitik in Slowenien, 1941-1945. Maribor, 1980.

United States, National Archives. Record Group

Germany, Federal Republic of, Bundesministerium für Vertriebene, Flüchtlinge und Kriegsgeschädigte. Dokumentation der Vertreibung der Deutschen aus Ost-Mitteleuropa. Vol. 5, Das Schicksal der Deutschen in Jugoslawien. Dusseldorf, I96I.

Stanić, Milan, ed. Sudjenje Lisaku, Stepincu, Šaliću i družini, Ustaško-Križarskim zločincima i njihovim pomagačima. Zagreb, 1946 .

United Kingdom, War Office.

Yugoslavia. Archives of the Institute of Military History, Belgrade.

-Documents of Commission for Ascertainment of

Crimes ... by Occupiers and Their Helpers

-Independent State of Croatia Documents

-Documents of Enemy Units

-German Documents

-Documents of National Liberation War

-Nedić Government Documents

Yugoslavia. Archives of the Institute for the History of the Workers' Movement of Croatia. Communist Party Documents.

Yugoslavia, F. P. R. of, Institute for the History of the Workers' Movement of Croatia. Zemaljsko antifasističko vijeće narodnog oslobodjenja Hrvatske. Zbornik dokumenata, 1943. Zagreb, 1964. Zbornik dokumenata, 1944. Zagreb, 1970.

Yugoslavia, F. P. R. of, Vojnoistorijski institut. Zbornik dokumenata i podataka o narodnooslobodilackom ratu jugoslovenskib naroda. 15 vols. in over 173 bks. to date. Belgrade, 1949-. 
Zbornik zakona i nare- Croatia, Independent State of, Ministry of Justice and Relidaba NDH, I94I [ [942, gion. Zbornik zakona i naredaba Nezavisne Države HrvatI943, I944] ske.

I94I. Zagreb, I942.

1942. 2 vols., consecutively paginated. Zagreb, 1942 . 1943. Zagreb, I943.

1944. Zagreb, I944. 



\author{
War and Revolution \\ in Yugoslavia, I94I-I945 \\ Occupation and Collaboration
}


